\title{
The relative values of cereal proteins for chick growth
}

\author{
By J. DAVIDSON, J. MATHIESON AND R. B. WILLIAMS \\ Rowett Research Institute, Bucksburn, Aberdeen \\ (Received 24 Fanuary I962-Revised I I April I962)
}

Many studies have been undertaken in the past half century to assess the relative values, for production, of the proteins in those cereals most commonly used in the feeding of non-ruminant animals. Cereals are usually regarded in the first place as a major source of energy, but they incidentally supply from one- to two-thirds or more of the dietary protein requirement. For poultry the proportion of protein provided by the cereal part of the diet is about one-third when the bird is young and increases to about two-thirds in the adult bird as the need for protein in the diet is reduced.

Both the species of animal used to assess the worth of cereal protein and the manner in which the protein has been administered have varied. In some tests the cereals have been given alone and in others with some common basal mixture. On several occasions one or other of the cereal proteins has been shown to be superior to the others tested, either in digestibility or in utilization of the digested nitrogen or in both, but the general impression has remained that there is no appreciable difference in overall protein value. One would expect, however, from tables of amino acid composition such as those of de Man \& Zwiep (I955), that oat protein

Table I. Contents of essential amino acids in cereal proteins, expressed as a percentage of the requirements of the chick stated by the (USA) National Research Council: Committee on Animal Nutrition (1960)

\begin{tabular}{|c|c|c|c|c|c|c|c|c|c|c|c|}
\hline rotein source & $\begin{array}{c}\text { PHE } \\
+ \\
\text { TYR } \\
(7 \cdot 0)\end{array}$ & $\begin{array}{l}\text { LEU } \\
(7 \cdot 0)\end{array}$ & $\begin{array}{l}\text { ARG } \\
(6 \cdot 0)\end{array}$ & $\begin{array}{r}\text { GLY } \\
(5 \cdot 0)\end{array}$ & $\begin{array}{l}\text { LYS } \\
\left(5^{\circ} 0\right)\end{array}$ & $\begin{array}{c}\text { MET } \\
+ \\
\text { CYS } \\
(4 \cdot 0)\end{array}$ & $\begin{array}{l}\text { VAL } \\
(4 \cdot 0)\end{array}$ & $\begin{array}{c}\text { ILEU } \\
\left(3^{\prime} \cdot 0\right)\end{array}$ & $\begin{array}{l}\text { THR } \\
(3 \cdot 0)\end{array}$ & $\begin{array}{l}\text { TRY } \\
(1 \cdot 0)\end{array}$ & $\begin{array}{l}\text { HIS } \\
\left(\mathrm{I}^{\prime} 5\right)\end{array}$ \\
\hline Whe & 126 & 90 & 73 & I 42 & 54 & 85 & II 2 & 133 & 97 & IIO & 140 \\
\hline & I 37 & ro3 & 100 & 82 & 66 & 87 & $13^{\circ}$ & 153 & 100 & 130 & 140 \\
\hline Barl & 120 & 94 & 80 & 94 & 60 & 85 & II7 & 133 & IIO & 100 & 133 \\
\hline Maize & I 40 & 178 & 80 & 72 & $5^{6}$ & 97 & 127 & I33 & II 3 & 80 & 153 \\
\hline $\begin{array}{l}\text { Wheat } \\
\text { gluten }\end{array}$ & II 3 & 96 & 62 & 68 & 38 & 97 & 102 & 140 & 87 & 100 & 140 \\
\hline
\end{tabular}

Values in parentheses are the NRC requirements expressed as a percentage of the protein.

would be superior to that of barley, wheat or maize for promoting growth in young chicks, because by calculation it has the highest content of lysine, which is the limiting amino acid for growth (Table $\mathrm{r}$ ).

Studies to date with rats (Osborne \& Mendel, I920; Jones, Caldwell \& Widness, 1948; Sure \& House, I948), pigs (McCollum, 1914) and poultry (Van Landingham, 
Clark \& Schneider, I945; Carpenter \& Clegg, I957) have relied mainly on growth-rate or nitrogen-balance techniques which give an indirect measure of nitrogen retention.

In our study we used carcass-analysis techniques and thus obtained a more direct measure of the nitrogen laid down in the growing chick.

\section{EXPERIMENTAL AND RESULTS}

\section{Experiments I and 2}

Diets (Table 2). In order to ensure that an excess of protein would not obscure amino acid deficiencies in the protein tested, a protein content of around $\mathrm{Ir} \%$ and a metabolizable energy content of $2600 \mathrm{kcal} / \mathrm{kg}$ were chosen for the diets. This protein level could not be achieved with cereals alone because of the feeding-stuffs required

Table 2. Expts $\mathrm{I}$ and 2. Percentage composition of diets

\begin{tabular}{|c|c|c|c|c|}
\hline Ingredient & $\begin{array}{c}\text { Wheat } \\
\text { diet }\end{array}$ & $\begin{array}{l}\text { Oat } \\
\text { diet }\end{array}$ & $\begin{array}{c}\text { Barley } \\
\text { diet }\end{array}$ & $\begin{array}{c}\text { Maize } \\
\text { diet }\end{array}$ \\
\hline Wheat, coarsely ground & $64 \cdot 5$ & - & - & - \\
\hline Oats, Sussex-ground & - & $70 \cdot 5$ & - & - \\
\hline Barley, ground & $\longrightarrow$ & $\cdots$ & $70 \cdot 5$ & - \\
\hline Maize, ground & - & $\cdots$ & - & $69 \cdot 0$ \\
\hline Oat feed & $17 \cdot 0$ & 一 & 9.5 & $20 \cdot 0$ \\
\hline Wheat gluten & $5^{\circ} \mathrm{O}$ & $5 \cdot 0$ & 5.0 & $5 \cdot 0$ \\
\hline Dried yeast & $I \cdot 0$ & I.O & $1 \cdot 0$ & 1.0 \\
\hline Vitamin supplement* & $I \cdot 5$ & $\mathrm{I} \cdot 5$ & $I \cdot 5$ & $\mathrm{I} \cdot 5$ \\
\hline Choline supplement & 0.5 & 0.5 & 0.5 & 0.5 \\
\hline Vitamin $B_{12}$ supplement $\downarrow$ & 0.02 & 0.02 & 0.02 & 0.02 \\
\hline $\mathrm{Ca}_{3}\left(\mathrm{PO}_{4}\right)_{2}$ & $2 \cdot 0$ & $2 \cdot 0$ & $2 \cdot 0$ & $2 \cdot 0$ \\
\hline $\mathrm{CaCO}_{3}$ & 0.5 & 0.5 & 0.5 & 0.5 \\
\hline $\mathrm{NaCl}$ & 0.5 & 0.5 & 0.5 & 0.5 \\
\hline \multirow[t]{2}{*}{ Maize starch } & $7 \cdot 5$ & $18 \cdot 5$ & $9 \cdot 0$ & - \\
\hline & 100.0 & 100.0 & 100.0 & 100.0 \\
\hline
\end{tabular}

* Commercial preparation containing, per $10 \mathrm{lb}, 4000000$ i.u. vitamin A, 2000000 i.u. cholecalciferol, $2 \mathrm{~g}$ riboflavin, $2 \mathrm{mg}$ vitamin $\mathrm{B}_{12}$, $10 \mathrm{~g}$ nicotinic acid, $2 \mathrm{~g}$ pantothenic acid, $\mathrm{I} \mathrm{g}$ vitamin $\mathrm{E}, 25 \mathrm{~g} \mathrm{Fe}$, $36 \mathrm{~g} \mathrm{Mn}, 7 \mathrm{~g} \mathrm{Cu}, 3 \mathrm{~g}$ Co, $10 \mathrm{~g} \mathrm{I}, 23 \mathrm{~g} \mathrm{Zn} \mathrm{(V.} \mathrm{W.} \mathrm{Eves} \mathrm{\&} \mathrm{Co.} \mathrm{Ltd,} \mathrm{Ilford,} \mathrm{Essex,} \mathrm{1959).}$

$\dagger$ Commercial preparation containing $25 \%$ choline chloride (V. W. Eves \& Co. Ltd, Ilford, Essex).

$\ddagger$ Commercial preparation containing ${ }_{5} \mu \mathrm{g}$ vitamin $B_{12} / g$ (Distillers Co. Ltd, Speke, Liverpool).

to balance the diets for indigestible organic matter (IOM) and energy. Of the II $\%$ protein therefore, some $4 \%$ was provided by wheat gluten, which, being a cereal protein itself with an amino acid pattern similar to that of cereals (Table I), was not expected to interfere appreciably in the comparison. Dried yeast, added for its vitamin content, provided $0.4 \%$ protein, oat feed, added to maintain a constant fibre content of $6 \%$, provided up to $0.9 \%$ protein, and the remaining protein was derived from the test cereal. The IOM content of each diet was calculated to be about $22 \%$. Calcium and phosphorus contents were adjusted to requirement by the addition of $\mathrm{Ca}_{3}\left(\mathrm{PO}_{4}\right)_{2}$ and $\mathrm{CaCO}_{3}$. The maize starch added to the diet brought the metabolizable energy (ME) content of each diet to approximately the same figure, and the resultant crude protein (CP): ME ratio of 0.044 was well below the critical level of about 0.06 (Davidson, McDonald, Mathieson \& Williams, 196r). The necessary vitamin supplements were added to each diet. 
Procedure. In Expt 1,200 day-old Rhode Island Red $\times$ White Leghorn cockerels, and in Expt 2, 200 day-old Rhode Island Red $\times$ Light Sussex cockerels were fed on equal parts of coarsely ground maize and wheat for a preliminary period of 4 days. They were then weighed, birds of extremely high or low weight were discarded, twelve of the remainder were killed and analysed, and forty-eight plus six spares were randomized to treatments and individual cages. After the contents of the alimentary tract had been removed the carcasses of the twelve birds representing those at the beginning of the experiment were minced, freeze-dried and analysed as described elsewhere (Davidson et al. 196I) for assessment of the composition of the experimental birds at the beginning of the period.

The experimental birds were fed $a d l i b$. and were weighed every and day. Food spilled was separated from droppings every and day and fed back.

After 4 weeks the birds were killed and analysed individually.

Table 3. Expts I and 2. Mean weight gains and protein retentions, between I and 4 weeks old, of groups of twelve chicks fed and analysed individually

\begin{tabular}{|c|c|c|c|c|c|}
\hline \multicolumn{6}{|c|}{ Type of diet } \\
\hline & Wheat & Oats & Barley & Maize & $\begin{array}{l}\text { SE of } \\
\text { differences }\end{array}$ \\
\hline \multicolumn{6}{|c|}{ Expt $r$} \\
\hline Weight gain $(g)$ & $44 \cdot I$ & $60 \cdot 8$ & $55 \cdot \mathrm{I}$ & $46 \cdot 1$ & $\pm 2 \cdot 84$ \\
\hline Protein $(\mathrm{N} \times 6 \cdot 25)$ gain $(\mathrm{g})$ & $8 \cdot 0$ & 10.7 & $9 \cdot 6$ & $8 \cdot 2$ & \pm 0.39 \\
\hline $\begin{array}{l}\text { Regression of protein gain } \\
\text { on weight gain }\end{array}$ & \multicolumn{5}{|c|}{$\begin{array}{l}\text { Protein gain }=(0.1 \text { I I } \pm 0.021) \text { weight gain }+3.4 \mathrm{I} \\
\text { Residual standard deviation }= \pm 0.56\end{array}$} \\
\hline $\begin{array}{l}\text { Retention of dietary protein } \\
(\%)\end{array}$ & $25 \cdot 0$ & $3^{1 \cdot 5}$ & $27 \cdot 8$ & $25 \cdot 9$ & \pm 0.75 \\
\hline \multicolumn{6}{|c|}{ Expt 2} \\
\hline Weight gain (g) & $47 \cdot 0$ & $50 \cdot 2$ & $57 \cdot 6$ & $37 \cdot 8$ & \pm 3.90 \\
\hline Protein gain $(\mathrm{g})$ & $8 \cdot 4$ & $8 \cdot 5$ & 10.5 & $6 \cdot 2$ & \pm 0.60 \\
\hline $\begin{array}{l}\text { Regression of protein gain } \\
\text { on weight gain }\end{array}$ & \multicolumn{5}{|c|}{$\begin{array}{l}\text { Protein gain }=(0.136 \pm 0.018) \text { weight gain }+x .83 \\
\text { Residual standard deviation }= \pm 0.68\end{array}$} \\
\hline $\begin{array}{l}\text { Retention of dietary protein } \\
(\%)\end{array}$ & $24 \%$ & $28 \cdot 7$ & $27 \cdot 2$ & $22 \cdot 3$ & \pm 0.90 \\
\hline \multicolumn{6}{|c|}{ Expts $I$ and 2 combined } \\
\hline $\begin{array}{l}\text { Weight gain }(\mathrm{g}) \\
\text { Regression of protein gain } \\
\text { on weight gain }\end{array}$ & \multicolumn{5}{|c|}{$\begin{array}{l}\text { Protein gain }=(0.128 \pm 0.014) \text { weight gain }+2.54 \text { (Expt } r) \text {, } \\
\text { or } 2.22 \text { (Expt } 2) \\
\quad \text { Residual standard deviation }= \pm 0.63\end{array}$} \\
\hline $\begin{array}{l}\text { Retention of dietary protein } \\
(\%)\end{array}$ & 247 & $3^{0 \cdot 1}$ & $27 \cdot 5$ & $24 \cdot 1$ & \pm 0.59 \\
\hline
\end{tabular}

Results. Table 3 shows the live-weight and protein gains, the relationship between them, and the percentage of dietary protein retained in the body. Efficiency of conversion of food protein into body protein was in the order: in Expt $\mathrm{I}$, oats $>$ barley $>$ maize or wheat; in Expt 2, oats or barley > maize > wheat; in the combined results, oats $>$ barley $>$ maize or wheat.

The regression equations relating protein gain and live-weight gain imply that even with no increase in weight there would be protein deposition in the young bird. This finding led to the determination of feather and non-feather protein separately in Expt 3, to locate, if possible, the site of this continuing deposition of protein. 


\section{Experiment 3}

Diets. The percentages of dietary protein retained by birds in Expts I and 2 appeared to be related in an inverse way to the amount of oat feed in the diet. The wheat and maize diets, for example, containing 20 and $17 \%$ oat feed respectively, gave rise to the poorest retention of dietary protein. It may be that the protein in this oat feed, which formed a small and variable part of the total protein in the barley, wheat and maize diets, was poorly digested, perhaps owing to some feature in its preparation. In formulating diets for the third experiment, therefore, the contribution of crude protein from each test cereal was made the same, and crude protein from oat feed added to equalize fibre contents was additional.

Table 4. Expt 3. Percentage composition of diets

\begin{tabular}{|c|c|c|c|c|}
\hline Ingredient & $\begin{array}{c}\text { Wheat } \\
\text { diet }\end{array}$ & $\begin{array}{l}\text { Oat } \\
\text { diet }\end{array}$ & $\begin{array}{c}\text { Barley } \\
\text { diet }\end{array}$ & $\begin{array}{c}\text { Maize } \\
\text { diet }\end{array}$ \\
\hline Wheat, coarsely ground & $78 \cdot 5$ & - & - & - \\
\hline Oats, Sussex-ground & - & $62 \cdot I$ & - & - \\
\hline Barley, ground & 一 & - & $78 \cdot 0$ & - \\
\hline Maize, ground & - & - & - & $76 \cdot 1$ \\
\hline Oat feed & 10.7 & 0.0 & $3 \cdot 7$ & $14 \cdot 0$ \\
\hline Wheat gluten & $4 \cdot 2$ & $4 \cdot 2$ & $4 \cdot 2$ & $4^{-2}$ \\
\hline Dried yeast & 0.9 & 0.9 & 0.9 & 0.9 \\
\hline Vitamin supplement* & $I \cdot 4$ & $I \cdot 4$ & $I \cdot 4$ & $x \cdot 4$ \\
\hline Choline supplement* & 0.5 & 0.5 & 0.5 & 0.5 \\
\hline Vitamin $B_{12}$ supplement* & 0.02 & 0.02 & 0.02 & 0.02 \\
\hline $\mathrm{Ca}_{3}\left(\mathrm{PO}_{4}\right)_{2}$ & $I \cdot 9$ & $I \cdot 9$ & $1 \cdot 9$ & $\mathrm{I} \cdot 9$ \\
\hline $\mathrm{CaCO}_{3}$ & 0.5 & 0.5 & 0.5 & 0.5 \\
\hline $\mathrm{NaCl}$ & 0.5 & 0.5 & 0.5 & 0.5 \\
\hline \multirow[t]{2}{*}{ Maize starch } & 0.9 & $28 \cdot 0$ & $8 \cdot 4$ & - \\
\hline & $100 \cdot 0$ & $100 \cdot 0$ & $100 \cdot 0$ & $100 \cdot 0$ \\
\hline
\end{tabular}

Fresh samples of cereal were obtained for this experiment; the diets were as shown in Table 4. The wheat, oats, barley and maize diets were found to contain, respectively, 10.7, 10.5, 10.6 and 10.8\% crude protein.

Procedure. Two hundred day-old Rhode Island Red $\times$ White Leghorn cockerels treated as in Expts $I$ and 2 were randomized to treatments and individual cages at 4 days old. At the end of the 4 experimental weeks all the birds were killed.

In this experiment the procedure adopted for analysis was different from the previous one. Feathers and down were removed, weighed and digested in conc. $\mathrm{H}_{2} \mathrm{SO}_{4}$ for determination of feather protein. After removal of the contents of the alimentary tract, the whole feather-free empty carcass was partially digested in conc. $\mathrm{H}_{2} \mathrm{SO}_{4}$ in a $600 \mathrm{ml}$ beaker. A portion of the resultant slurry was digested with $\mathrm{H}_{2} \mathrm{SO}_{4}$ in a $\mathrm{Kjeldahl}$ flask, and the non-feather protein determined.

Results. From Table 5 it can be seen that the results were similar to those of Expts 1 and 2, i.e. protein conversion in order of efficiency was oats $>$ barley $>$ maize > wheat. 
Once again the regression equation of protein gain on live-weight gain showed an intercept indicating that even with no live-weight gain there would still be an increase in the protein content of the carcass with time.

Table 5. Expt 3. Mean weight gains and protein retentions, between $\mathrm{I}$ and 4 weeks old, of groups of twelve chicks fed and analysed individually

\begin{tabular}{|c|c|c|c|c|c|}
\hline & & Тур & & & \\
\hline & Wheat & Oats & Barley & Maize & differences \\
\hline Weight gain (g) & $37^{\cdot I}$ & $53 \cdot 1$ & $52 \cdot 3$ & $40 \cdot 7$ & \pm 3.9 \\
\hline Protein $(N \times 6.25)$ gain $(\mathrm{g})$ & $6 \cdot 63$ & $8 \cdot 47$ & 8.60 & 7.03 & \pm 0.48 \\
\hline Feather protein gain (g) & $I \cdot 18$ & $\mathrm{I} \cdot \mathrm{I} 8$ & $x \cdot 29$ & $r \cdot 19$ & \pm 0.14 \\
\hline Non-feather protein gain $(\mathrm{g})$ & 5.45 & $7 \cdot 28$ & $7 \cdot 31$ & $5 \cdot 84$ & \pm 0.45 \\
\hline $\begin{array}{l}\text { Regressions of protein gain } \\
\text { on weight gain }\end{array}$ & $\begin{array}{r}\text { Protei } \\
\text { RSI } \\
\text { Non-f } \\
\text { RSI }\end{array}$ & $\begin{array}{l}n=(0 . \\
\pm 0.46 ; \\
r \text { protei } \\
\pm 0.43 ;\end{array}$ & $\begin{array}{l}.008) \mathrm{w} \\
\text { intercer } \\
=(0.10 \\
\text { interce }\end{array}$ & $\begin{array}{l}\text { gain }+2 \\
4 I)= \pm \\
.008) \text { we } \\
\pm 0.36\end{array}$ & gain $+1 \cdot 52$ \\
\hline Retention of dietary protein & $24 \cdot 7$ & $30 \cdot 5$ & $28 \cdot 5$ & 26.5 & \pm 0.76 \\
\hline
\end{tabular}

Even when the protein gain in the feathers was subtracted from the total protein gain there was in the resultant regression equation of non-feather protein gain on weight gain a significant intercept which amounted to more than half the intercept when total protein gain was considered. It appears therefore that the protein gain in feathers may account for some but not all of a relatively constant deposition of protein which occurs with advancing age even when weight gain is very small or nil. The site of the non-feather protein deposition under these circumstances is not known.

\section{DISCUSSION}

These experiments, carried out on two sets of cereal samples, indicate that the value of cereal proteins for promoting growth in young chicks is in the order oats $>$ barley $>$ maize or wheat. It may be that not all samples of these cereals would be placed in this order; the factors influencing amino acid composition of cereal proteins are still a matter of controversy, climate, fertilizer treatment and genetical factors being known to influence crude-protein content (see review by Duckworth, 1952) and both positive and negative correlations having been found between amino-acid and crude-protein contents. For lysine contents both positive (Miller, Aurand \& Flach, 1950) and negative (Sauberlich, Chang \& Salmon, 1953) correlations have been found with maize, and a negative correlation with wheat (McElroy, Clandinin, Lobay \& Pethybridge, 1949; Price, 1950). Recent work (Wolfe \& Fowden, 1957) shows that the amino acid composition of the protein can vary widely in samples of maize having approximately the same protein content, the differences being greater between varieties of widely different genetical strains.

The results presented by us here, however, are not entirely unexpected, at least for oats. As mentioned previously, comparison of the amino acid requirements of the chick with the amino acid composition of cereals, as given in tables of average 
values, indicates that lysine is limiting for growth. Moreover, according to these tables oat protein supplies a greater amount of lysine than the other cereal proteins, so that the oat diet would be expected to support better growth if the digestibility of each protein is about the same. The inclusion in each diet of a constant proportion of wheat gluten should not invalidate the comparison, because the amino acid pattern of this protein is similar to that of other cereal proteins with a relatively low content of lysine.

In the compounding of diets for chicks, an increased value of oat protein for growth, probably owing to its higher lysine content, would have to be set against its high content of IOM, a factor that might tend to reduce the amount of food eaten owing to reduced acceptability if the content of oats was too high.

The observation that the percentage of protein contributing to the live-weight gain increases as the rate of growth in early life decreases has been made in previous experiments at the Rowett Institute. The equations indicate that live-weight gain in the young chick up to 4 weeks of age has certain limitations as a guide to protein retention at low rates of gain when the size of the constant in the equation is relatively large compared with the 'weight-gain' function. The expression derived for the relationship between non-feather protein and live-weight gain (Table 5) suggests that tissues other than the feathers develop with age, irrespective of weight gain. It may be that bone and vital organs are involved, because results from a study of growth in the domestic fowl (Wilson, 1954) indicate that on a low plane of nutrition bone and viscera (heart, spleen, pancreas, liver, lungs and kidneys) develop in preference to muscle during the first few weeks of life.

\section{SUMMARY}

I. In three experiments carried out with groups of twelve individually caged chicks fed on all-cereal diets $a d$ lib. between I and 4 weeks of age, a carcass-analysis technique was used to assess the relative values of the proteins of wheat, oats, barley and maize for promoting deposition of body nitrogen.

2. In each experiment the diets were designed to contain the same crude-protein concentration, in the region of $\mathrm{i} \% \%$, with about $7 \%$ derived from the test cereals and $4 \%$ from wheat gluten which has an amino-acid pattern similar to those of the test cereals. Adequate metabolizable energy was provided by the addition of maize starch where necessary.

3. The order of the values found was oats $>$ barley $>$ maize or wheat, a result to be expected from the amino-acid make-up of these cereals and the amino acid requirements of the chick.

4. Regression equations relating protein gain and live-weight gain indicated that there is in the growing chick a relatively constant deposition of protein independent of live-weight gain. One site of such protein deposition is the feathers.

We are grateful to Mr A.W. Boyne for the statistical analyses and to Mr L. J. Dekanski for technical assistance. 


\section{REFERENCES}

Carpenter, K. J. \& Clegg, K. M. (1957). Brit. F. Nutr. I1, 358.

Davidson, J., McDonald, I., Mathieson, J. \& Williams, R. B. (1961). F. Sci. Fd Agric. 12, 425.

de Man, T. J. \& Zwiep, N. (1955). Voeding, r6, 147.

Duckworth, J. (1952). Chem. E Ind. p. Ir 39.

Jones, D. B., Caldwell, A. \& Widness, K. D. (1948). F. Nutr. 35, 639.

McCollum, E. V. (1914). F. biol. Chem. 19, 323.

McElroy, L. W., Clandinin, D. R., Lobay, W. \& Pethybridge, S. I. (1949). F. Nutr. 37, 329.

Miller, R. C., Aurand, L. W. \& Flach, W. R. (1950). Science, r12, 57.

National Research Council: Committee on Animal Nutrition (I960). Publ. nat. Res. Coun., Wash., no. 827 .

Osborne, T. B. \& Mendel, L. B. (I920). F. biol. Chem. 4r, 275.

Price, S. A. (1950). Cereal Chem. 27, 73.

Sauberlich, H. E., Chang, W.-Y. \& Salmon, W. D. (1953). F. Nutr. 51, 241.

Sure, B. \& House, F. (1 948). F. Nutr. 36, 595.

Van Landingham, A. H., Clark, 'T. B. \& Schneider, B. H. (1945). Poult. Sci. 24, 105.

Wilson, P. N. (1954). F. agric. Sci. 44, 67.

Wolfe, M. \& Fowden, L. (1957). Cereal Chem. 34, 286. 